\title{
Democracy is healthier - health in Poland in the late 1980s and 1990s
}

\author{
Witold A. Zatoński ${ }^{1,2}$, Mateusz Zatoński ${ }^{1,3}$ \\ ${ }^{1}$ Health Promotion Foundation, Nadarzyn, Poland \\ 2Maria Skłodowska-Curie Memorial Cancer Center and Institute of Oncology, Warsaw, Poland \\ ${ }^{3}$ London School of Hygiene and Tropical Medicine, London, UK
}

\begin{abstract}
The collapse of the communist regime in Poland at the end of the 1980s, followed by the opening of the country to market economy, precipitated a "natural experiment" in population health. Poland emerged from communism with very poor health indicators, high rates of lung cancer and cardiovascular diseases. In the years immediately following the collapse of communism the situation deteriorated further, as a surge in alcohol consumption led to a dramatic increase in premature mortality. However, after 1991 the health situation of the Polish population began to improve. Mortality rates began to decline for all age groups, driven mainly by the decline in cardiovascular disease morbidity and mortality. One reason for this health improvement can be sought in the $10 \%$ decrease in smoking prevalence that took place in the 1990s, and was stimulated by the implementation of very progressive anti-tobacco legislation. Another contributor was the reversal in alcohol consumption trends, with alcohol consumption falling from 11 litres in 1991 to 8.5-9 litres in 1995. However, the chief reason for the rapid improvement in health were the revolutionary changes in the diet of Poles - the fall in animal fat consumption compensated by the increase in vegetable fat consumption, and the increase in the consumption of fruits and vegetable. The resulting increase in life expectancy between 1991 and 2002 among Polish women was the fastest in Europe, and among Polish men it was the third fastest.
\end{abstract}

KEY WORDS: health improvement, Poland, smoking, alcohol, diet, cardiovascular health.

ADDRESS FOR CORRESPONDENCE: Prof. Witold A. Zatoński, Health Promotion Foundation, 51 Mszczonowska St., 05-830 Nadarzyn, Poland, phone: +48 22739 76 40, e-mail: wazatonski@promocjazdrowia.pl

\section{HEALTH DURING REGIME CHANGE}

As the communist regime in Poland was crumbling at the end of the 1980s, and the country was opening up to market economy, the prospects for the health of adult Poles looked rather bleak. Soaring rates of lung cancer, cardiovascular diseases (principally ischaemic heart disease), sudden deaths from external, non-medical causes (accidents, injuries, poisonings, etc.), and liver cirrhosis - these indicators of ill health in Poland reached levels not registered anywhere else in the world and contributed to a dramatic increase in premature deaths among young and middle aged Poles [1-15]. Mortality between 15 and 59 years of age among men in Poland was among the highest in the world, higher than in any other country outside sub-Saharan Africa (Fig. 1) [16]. This epidemic of mostly man-made diseases was one of the biggest challenges facing Poland as it was undergoing political and economic transformation.

An uncertain tomorrow, the impoverishment of society, the appearance of unemployment (an unknown phenomenon under communism), all seemed to augur the worst for the future of the health of Poles. Public health scholars forecasted a surge in mortality among newborn babies and children and the collapse of the health service; and a nation-wide health crisis due to malnutrition was commonly believed to be on the way. These fears seemed to come true as the first stage of systemic transition was marked by a severe mortality crisis in most 

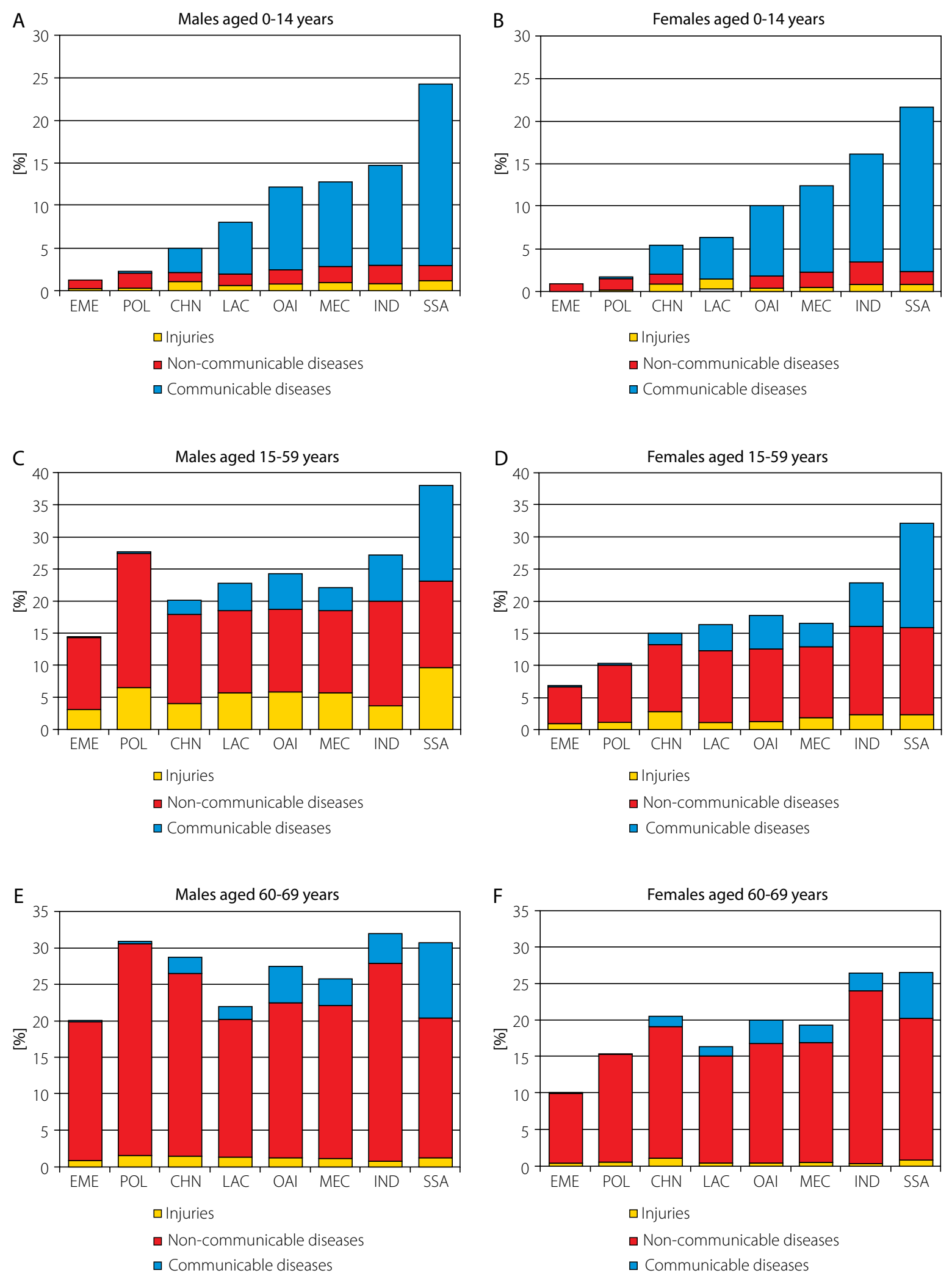

EME - Established Market Economies; POL - Poland; CHN - China; LAC - Latin America and the Caribbean; OAl - Other Asia and Islands; MEC - Middle Eastern Crescent; IND - India; SSA - Sub-Saharan Africa.

FIG. 1. Risk of dying across specified age intervals from three major cause of death categories: Poland and major global regions (data adapted for Poland) 
countries of the Central and Eastern European (CEE) region between the end of the 1980s and early 1990s [15, 17-20]. The only exception was Hungary, where a health decline was not observed in this period. The mortality crisis was on the whole less pronounced and lasted shorter in Central Europe, with the health decline no longer observed after 1991. Meanwhile, in the ex-Soviet countries, the dramatic increases in mortality continued until the mid-1990s. In Russia alone, between 1992 and 1994, there were $1,138,000$ more deaths altogether (743,000 among men and 395,000 among women), compared to 1991 (see: WHO Mortality Database).

At the beginning of the 1990s, a surge in alcohol consumption occurred in almost all CEE countries. This trend was first observed in Poland, and was driven by political developments. The collapse of the old political system between 1988 and 1989 and the prioritisation by politicians of easy access to goods over health considerations, paved the way for the influx into Poland of millions of gallons of untaxed, cheap, high-concentration alcohol (the Schnapsgate scandal). Sierosławski estimated on the basis of indirect indicators (e.g. the number of first episodes of alcoholic psychoses) that there was a dramatic rise in alcohol consumption in that period: from 6 to 10-11 litres of pure alcohol per capita per year [21]. An increase in alcohol abuse among Polish children was also observed, partly due to the extreme liberalisation of access to alcohol, whereupon alcoholic beverages became available at anytime and anywhere, including in newspaper kiosks [21, 22].

The surge in alcohol consumption was closely followed by a dramatic increase in premature mortality, mostly among adults (20-64 years), and especially among men. The health indicator most strongly connected with fluctuations in alcohol consumption in Poland (and other CEE countries) was sudden death from non-medical causes. The years 1988-1991 were marked by dramatic increases in sudden deaths in Poland. Injury-related mortality rates rose by as much as $32 \%$ in middle-aged (45-64 years) men, and by $27 \%$ in young adult (20-44 years) men (Fig. 2). A similar, but much less marked trend, was seen among women, mostly in the young adult group (20-44 years), where the increase was $26 \%$, and in the middle-aged group (45-64 years), where the increase was $21 \%$.

\section{HEALTH IMPROVEMENT AFTER 1991}

However, while the years immediately following the political transformation in Poland have brought the health decline forecasted by public health scholars, after 1991 unexpectedly almost all the health indicators began to improve dramatically. Mortality rates declined for all age groups (in men in 1991 they amounted to $1062 / 100,000$, in 2002 to $809 / 100,000$; in women to $550 / 100,000$ in 1991 and $412 / 100,000$ in 2002) [15]. The decline was particularly rapid for young adults (2044 years old) and middle age adults (45-64 years old).

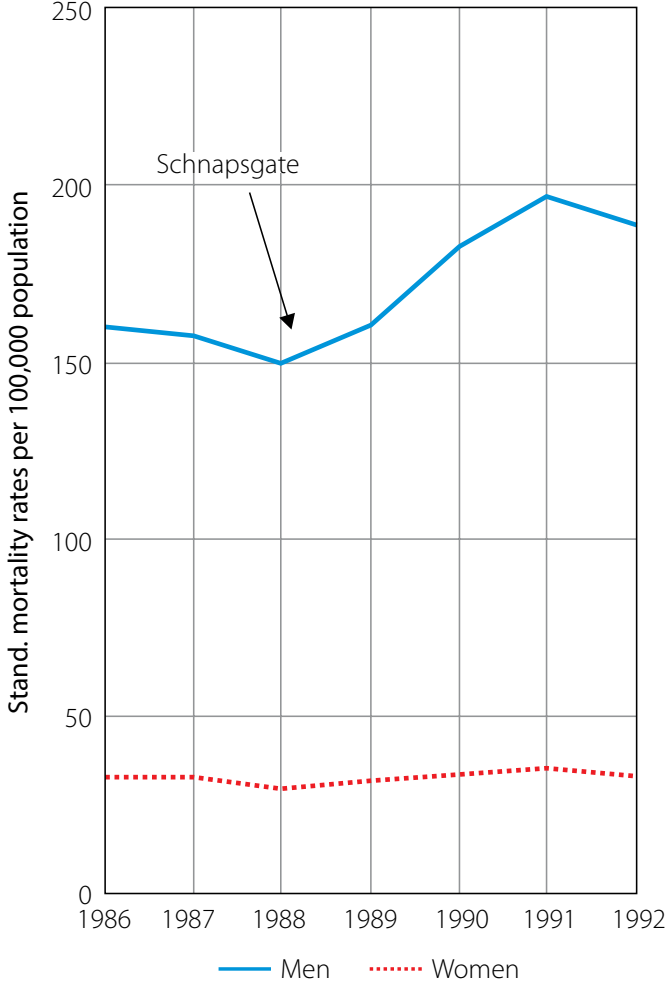

FIG. 2. Mortality from external causes of death, 45-64, Poland, 1986-1992

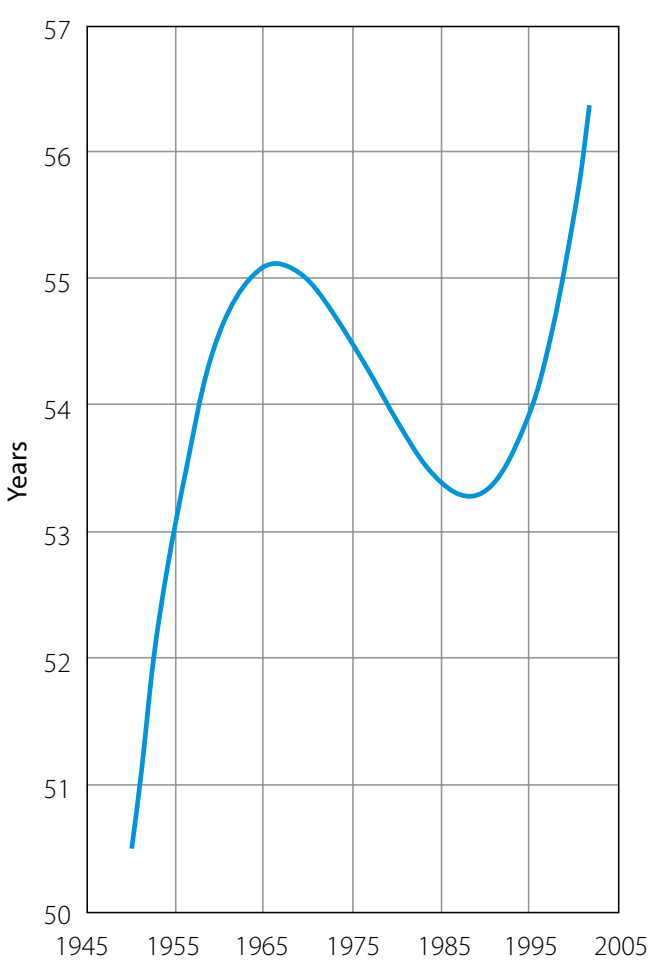

FIG. 3. Life expectancy at the age of 15, Poland, 1950-2002

After almost 30 years the trend of increasing premature mortality of adults was reversed (see Fig. 3). Despite the ageing of the population, in 2002 there were almost 


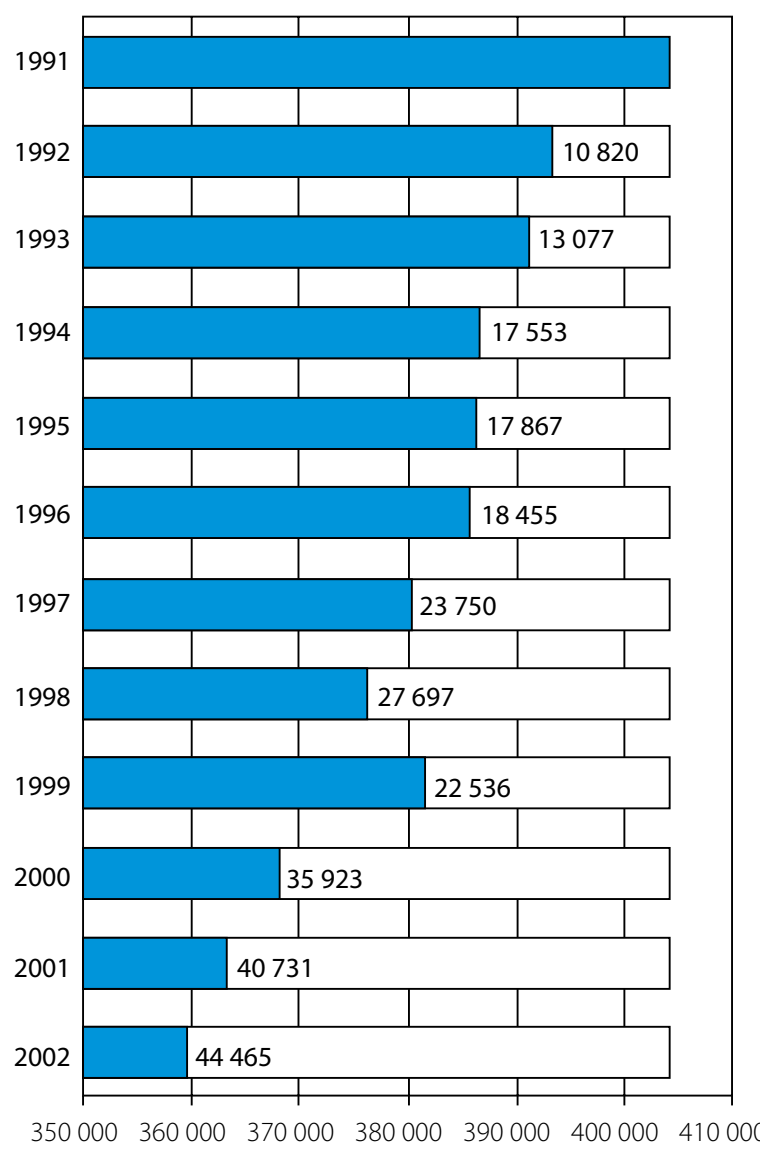

FIG. 4. The decrease in the annual number of deaths in Poland in the years 1992-2002 as compared to 1991, both sexes
44.5 thousand deaths less than in 1991 (a decline from 404 thousand deaths in 1991 to 359 thousand deaths in 2002) (Fig. 4). Between 1991 and 2002 the probability of death in the 20-64 age group decreased among men from $37.7 \%$ to $29.5 \%$ and in women from $15.7 \%$ to $12 \%$. In the period 1991-2002 infant mortality also declined, from 15 to 7.5 per 1000 live births [15].

The observed improvement in general health indicators can be chiefly attributed to the decrease in cardiovascular disease morbidity and mortality. This decline was very significant and applied equally to both sexes, all age groups, inhabitants of rural and urban areas, as well as people of all levels of education. In the years 1991-2002 cardiovascular disease mortality in both sexes decreased in the 20-44 age group by around 50\%, and in the 45-64 age group by around $40 \%$, while in the population aged above 65 by about 30\% (Fig. 5). The pace of decrease of cardiovascular disease mortality indicators in the years 1991-2002 in Poland was among the fastest in the world.

The improvement of health in Poland after 1991 could also be observed in other health indicators. Mortality due to non-medical causes, which reached its peak in 1991, has since then been declining in all groups, and particularly in men [15]. The trends of increase in lung cancer morbidity and mortality have also began to reverse, especially in younger age groups in both sexes. The general positive trend of decline of lung cancer mortality rates in the male population, as well as the decrease in mortality in the other tobacco-related cancer locations (e.g. laryngeal cancer, oral cancer,
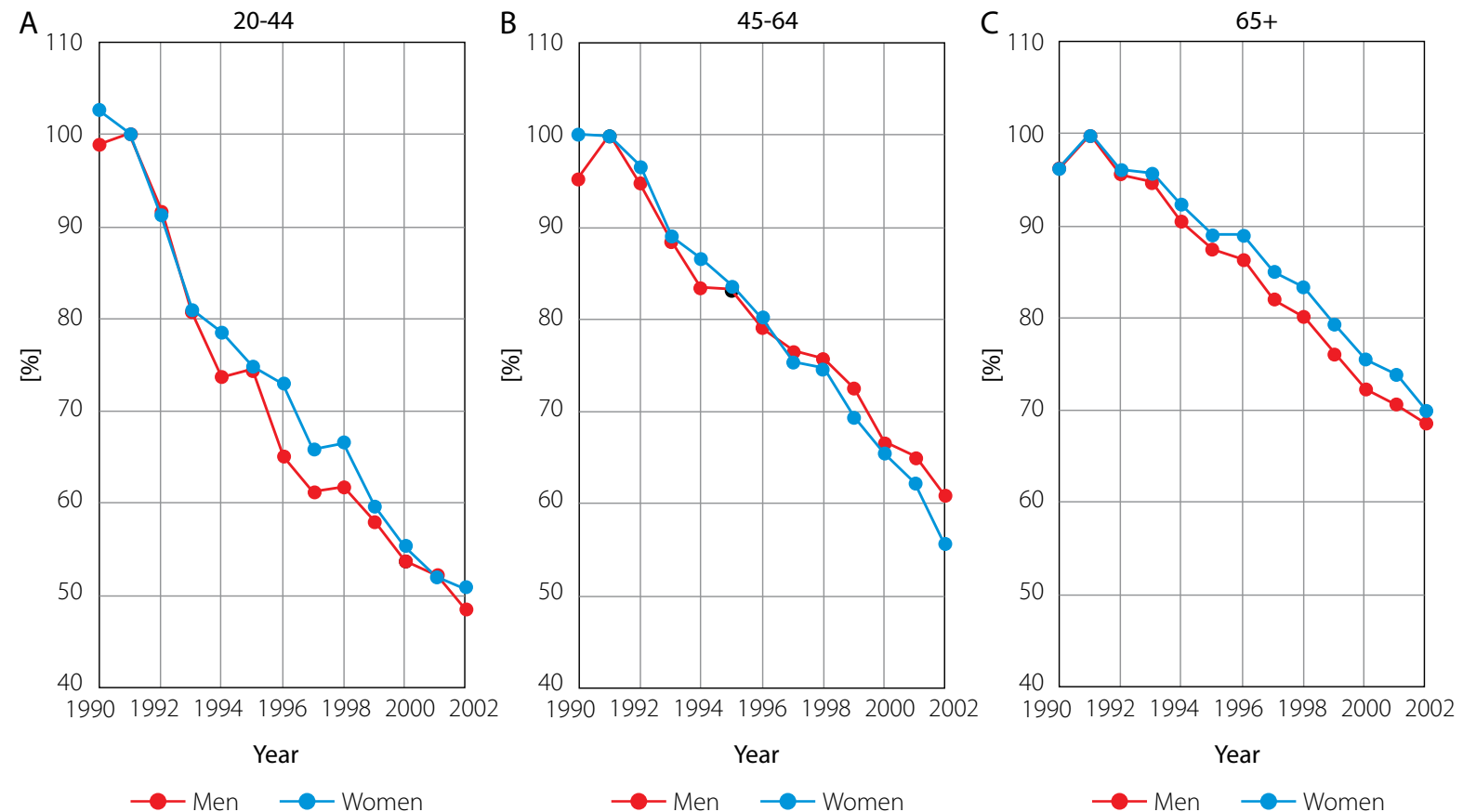

FIG. 5. Change in mortality rates from cardiovascular disease in percent (1991=100\%), Poland, 1990-2002 
etc.), has contributed to the general downward trend of cancer mortality in men [15]. The positive changes in the lung cancer situation in the 1990s in Poland are particularly striking, if compared with Hungary, where the increase in lung cancer mortality continued after the improvement in Poland began, and with USA, where the decrease in lung cancer mortality began two decades earlier (see Fig. 6).

A similar development of the health situation was observed in this period in the Czech Republic and Slovakia $[23,24]$. The main reason for the decline in adult premature mortality in these countries was also the rapid decrease of cardiovascular disease mortality. Interestingly, after 1995 the same phenomenon was observed also in Hungary, and, later also in the Baltic States. By the end of the 1990s, twenty years after Western Europe, the cardiovascular disease transformation was taking place in most CEE countries [15].

Between 1991 and 2002 Poland enjoyed a period of impressive gain in population health. Life expectancy increased by 4.5 years in men and 3 years in women. Among men life expectancy crossed the threshold of 70 years for the first time in 2002, and in women it amounted to 79 years. This meant that the increase in life expectancy between 1991 and 2002 among Polish women was the fastest in Europe, and among Polish men it was the third fastest [15].

A

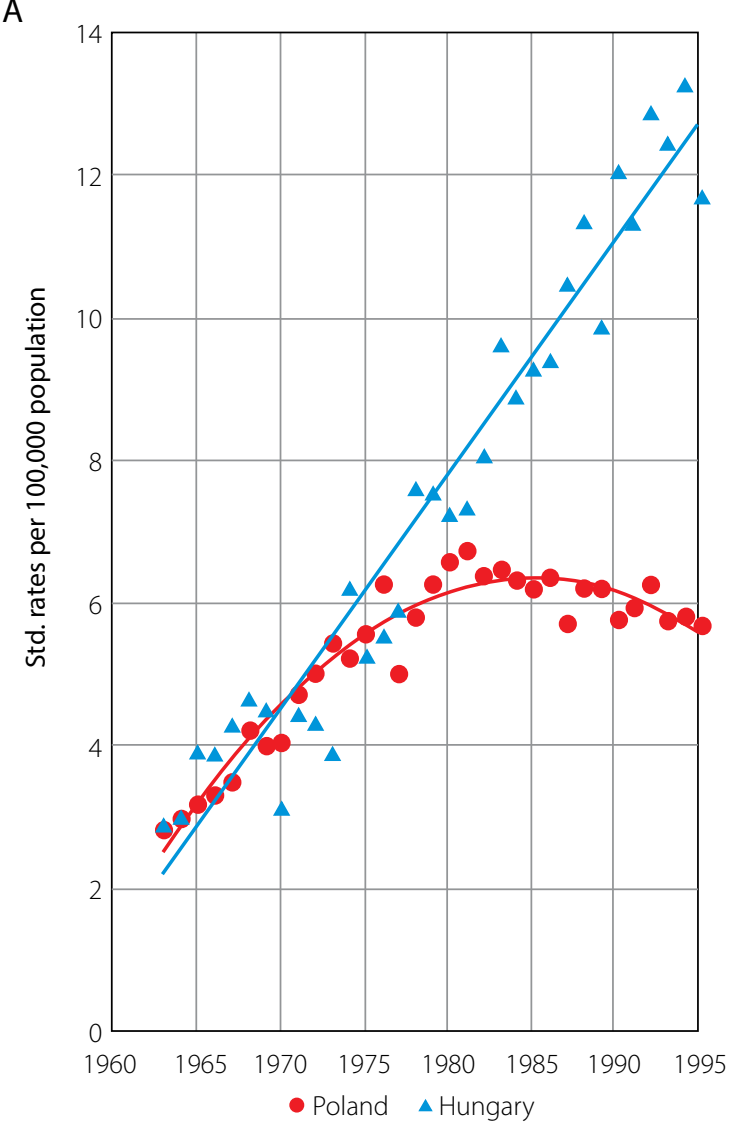

\section{MAIN REASONS FOR POLAND'S HEALTH IMPROVEMENT \\ SMOKING}

Since the early 1980s Poland experienced political chaos which significantly affected the health behaviour of Poles. In the early 1980s, due to economic and technological crisis, the production of tobacco products, which was entirely in the hands of the state, collapsed in Poland. Smokers began to have difficulties accessing cigarettes and in result their consumption and sale decreased. The government decided to begin rationing tobacco products and cigarette ration stamps were distributed among all working adults. The rationing decreased the number of cigarettes smoked in Poland. However, at the same time, the number of regular smokers actually increased, partly because some ex-smokers who received cigarette ration stamps picked up smoking again. Nonetheless, the cigarette rationing had certain positive social and health effects, such as the decrease of rates of smoking initiation among children, who were unable to access cigarettes as easily as before. By the second half of the 1980s cigarette rationing was ended as normal production was resumed, and the situation returned to its original state.

The regime transition of 1989 was followed by the immediate entrance of transnational tobacco companies (TTCs) on the Polish market, and by the mid-1990s

B

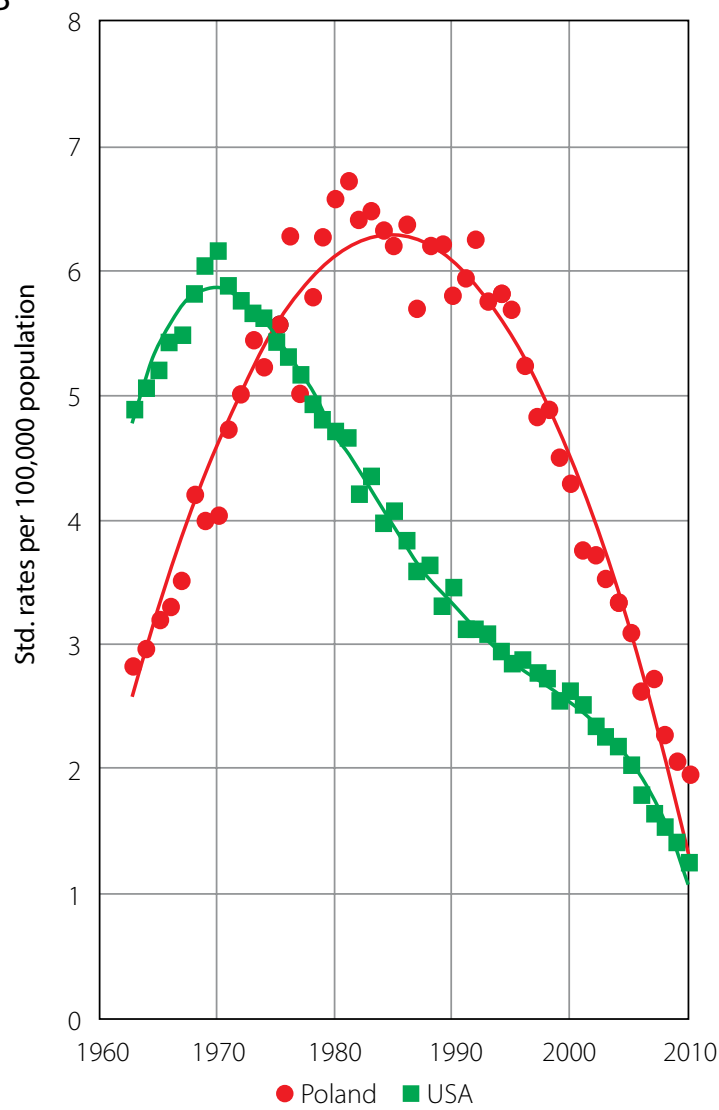

FIG. 6. Lung cancer mortality, men aged 20-44, Poland vs. Hungary and USA 
the privatization of the state tobacco industry. Shortages were quickly eliminated from the Polish market. The prices of cigarettes increased slightly in comparison to the prices in the 1980s. The normalization of the tobacco market in Poland coincided with the launch of aggressive advertisement campaigns and political lobbying by the TTCs. However, the expansion of the privatizing tobacco industry was moderated by the growing health advocacy movement in Poland. The medical community, followed suit by certain political factions in the Polish Parliament, started to demand that a comprehensive legislative solution be devised for the growing tobacco and cancer epidemic in Poland. At the same time, good health was becoming an increasingly important value for the Polish society. The enormous investments and aggressive tactic of the TTCs, in contrast to all predictions, did not lead to the expansion of the tobacco market in Poland. On the contrary, also due to the progressive anti-tobacco legislation of 1995/1996, sale of cigarettes in Poland decreased by $10 \%$ by the end of the 1990 s $[25,26]$. The decrease in tobacco consumption has led almost instantly to an improvement in health indicators. A more detailed analysis of the changes in tobacco control policy in Poland and its effects can be found in other articles in this publication (see: The Polish Anti-tobacco Law - 20 years on, p. 25, Poland's anti-tobacco advocacy - a historical outline, pp. 26-31, The significance and impact of the Polish Anti-tobacco Law, pp. 32-35, Evidence-based policy making? The case of Polish opposition to the EU Tobacco Products Directive, pp. 36-39, Trends in smoking among Polish and Norwegian youth 1986-2014, pp. 44-51).

\section{ALCOHOL}

The alcohol market in Poland was also denormalised by the political events. Throughout the 1980s the sale of registered alcohol experienced significant fluctuations. As the communist regime in Poland collapsed in 1989, along with it went the country's fiscal borders, resulting in the growth of an enormous black market for alcohol products. This applied especially to vodka, which in that period constituted $70 \%$ of the total alcohol consumption in Poland, and the prices of which fell to levels similar to the prices of water. Sierakowski [21] estimates that in the years 1988-1991 the consumption of alcohol in Poland increased by 4-5 litres of pure spirit per person per year. This trend in alcohol consumption in Poland was also reversed after 1991 as fiscal control was tightened; it is estimated that by 1995 alcohol consumption had fallen from 11 litres to 8.5-9 litres per capita [22]. Until the end of the 1990s significant changes were observed in the structure of alcohol consumption in Poland. The Polish alcohol market was dominated by the production and sale of vodka since the Second World War. In the 1990s vodka was increasingly replaced by beer, the consumption of which was increasing every year. The overall level of alcohol consumption, however, remained largely unchanged, at around 8-9 litres per capita per annum [27].

\section{DIET}

The introduction of market economy, including the abolition of food subsidies, as well as the opening up to the global food market and the decision to make the national currencies fully convertible, resulted in an enormous change of diet in Poland and some neighbouring countries of CEE. It seems that these significant dietary changes, which occurred in all age groups, in both sexes, and in all regions of Poland, might constitute the most important explanation for the reversal in epidemiological trends after 1991.

Generally, after 1988, the purchasing power of people in Poland has decreased. The practice of subsidizing food prices was abandoned at the same time. The prices of animal products rose, while vegetable products became relatively cheaper. The trend was accompanied by the appearance of new products (e.g. new types of fruits and vegetables), their high quality, efficient methods of distribution, continuous availability, and modern marketing techniques. These changes had a rapid and profound effect on the structure of consumption.

A higher consumption of fruits and vegetables has become a feature of the new diet. The increase in citrus fruit consumption can serve as one example of the changes brought about by market economy. After the Polish currency (zloty) became convertible and borders were opened, the Polish market was deluged with relatively cheap bananas, oranges, grapefruits, lemons and kiwis available all year round. The production of local fruits and vegetables also developed. Apples, peppers, berries (strawberries, blackberries, raspberries) became available also out of season. The consumption of vegetables and fruits significantly increased, also in the form of juices and in frozen form. Despite these positive changes, in the 1990s Poland still remained a country where the consumption of fruits and vegetables, fresh and processed, was rather low (150 kg per capita annually in Poland, compared to about $250 \mathrm{~kg}$ in western Europe and over $400 \mathrm{~kg}$ in Greece) [15].

New groups of food products appeared on the shop shelves and on people's tables. From 1989 to 1999 vegetable fat consumption rose from about $8.8 \mathrm{~kg}$ per capita to almost $17.8 \mathrm{~kg}$. An especially high increase was observed in the consumption of edible oil and soft margarine with low levels of trans fats, which were also increasingly commonly used with bread as butter substitutes. At the same time the consumption of animal fat fell, the decrease being most noticeable with regard to butter (from $8.8 \mathrm{~kg}$ per capita in 1989 to $4.6 \mathrm{~kg}$ in 1999), as well as red meat and full fat milk. It must be pointed out that these changes were only reflected in the structure of consumption of fats, with animal fat being replaced by vegetable fat, while the overall amount of fat consumed showed little 


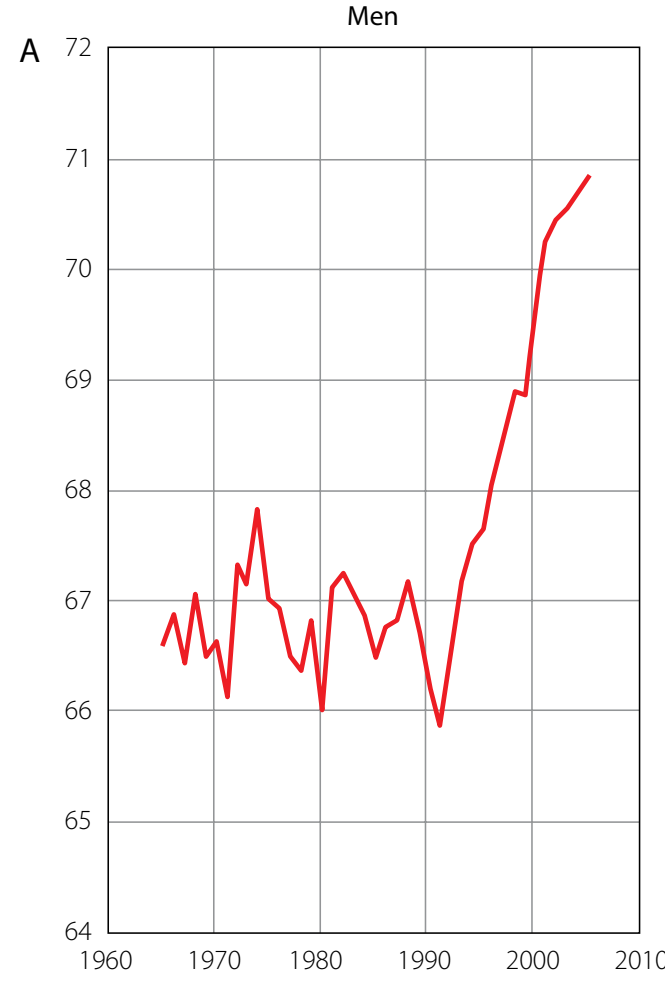

FIG. 7. Life expectancy at birth in Poland, 1965-2005

change. The end effect is that this essential element of people's diets by the end of the 1990s tended to consist more often of fats derived from oily plants $[13,28,29]$.

Vegetable oils (also in the form of soft margarine) are a type of fat that is essential for the human bodies to function properly. Studies indicate that increasing the amount of vegetable fat consumed provides for effective protection of the heart and blood vessels from disease. Evidence from controlled clinical studies of post-myocardial infarction patients demonstrates that replacement of animal fat with vegetable oils can significantly reduce coronary heart disease-related mortality within a short time. Transition to a Mediterranean diet (rather than a standard low-fat diet) was correlated with a $76 \%$ fall in cardiovascular disease (CVD) mortality within 27 months in one study [30]. Epidemiological studies prove that the type and structure of dietary fat consumption (increased share of vegetable fat) may produce a strong and rapid positive effect on CVD mortality [30]. It could be postulated, with all the limitations of such a claim, that a "natural experiment" corroborating these claims could be observed in Poland between the 1980s and 1990s, with the participation of the entire population (changes in fat consumption structure in Poland are described in more details in this issue in the article Unsaturated fat and cardiovascular health in Poland, pp. 63-66).

\section{CONCLUSIONS}

The political and economic changes that took place in CEE countries after 1989 had transformed key factors

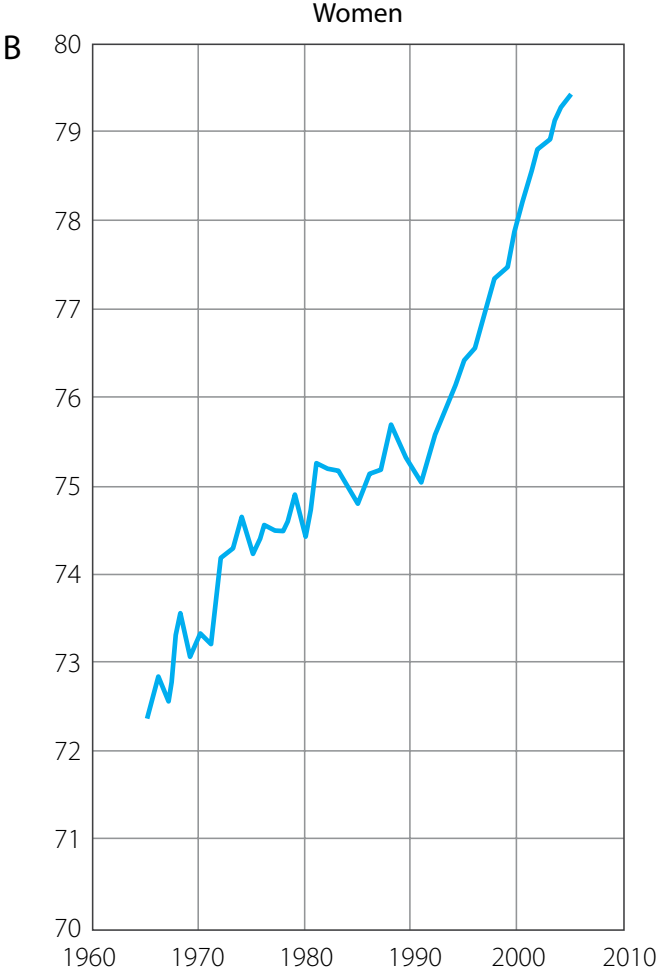

shaping the health of Poles, in effect leading to a population-wide "natural experiment". The shifts in health can be divided into two distinct phases. The first took place in the period 1988-1991, when the mortality from non-medical causes, especially among young men, increased due to a sudden rise in alcohol consumption. The second took place after 1991, when after 30 years of cardiovascular health deterioration, unexpectedly a major and sustained decrease in cardiovascular diseases began in Poland. It was driven principally by the changes in dietary patterns that followed the introduction of market economy in Poland. These changes were characterised by a rapid increase in consumption of vegetable fats, which replaced the previously dominant animal fats, while keeping the overall fat consumption at the same level. The positive effects these dietary changes had on the health of Poles are consistent with epidemiological studies associating the so-called "Mediterranean" diet with lower vascular death rates. They are also consistent with the effects of a similar shift in diet that occurred in the 1960s in Finland, which from the country with the highest animal fat consumption and highest cardiovascular disease morbidity and mortality in Europe, became a country with low risk of cardiovascular diseases. The improvement in cardiovascular health and the increase in life expectancy in both sexes in Poland in the 1990s belonged to the fastest in the world (Fig. 7).

\section{DISCLOSURE}

Authors report no conflict of interest. 


\section{References}

1. Zatoński W, Becker N, Gottesman K, et al. Atlas of cancer mortality in Poland 1975-1979. Springer-Verlag, Berlin 1988.

2. Doll R, Peto R, Bjartveit K, Chazova L, Cholmogorova G, Hiesch A, Levshin V, Simpson D, Zatoński W. Tobacco and death in Eastern Europe. In: Cancer prevention in Europe. Bodmer W, Zaridze D (eds.). Organization of European Cancer Institutes, London 1993; 71-97.

3. Zatoński W. Stan zdrowia Polaków [Health status of Poles]. Medycyna po Dyplomie 1994; 3: 15-22.

4. Feachem R. Health decline in Eastern Europe. Nature 1994; 367: 313-314.

5. Kubik AK, Parkin DM, Plesko I, Zatonski W, Kramarova E, Möhner M, Friedl HP, Juhasz L, Tzvetansky CG, Reissigova J. Patterns of cigarette sales and lung cancer mortality in some central and eastern European countries, 1960-1989. Cancer 1995; 75: 24522460.

6. Zatoński W. The health of the Polish population. Public Health Rev Israel 1995; 23: 139-156.

7. Zatoński W, Smans M, Tyczyński J, Boyle P (eds.). Atlas of cancer mortality in Central Europe. IARC Scientific Publications no. 134. International Agency for Research on Cancer, Lyon 1995.

8. McMichael AJ, Zatoński W. Environmental, behavioral, and socio-economic influences: tackling the historical jigsaw puzzle of health in Central and Eastern Europe. Int J Occup Environmental Health 1996; 2: 161-163.

9. Fagerstrom KO, Kunze M, Schoberberger R, et al. Nicotine dependence versus smoking prevalence: comparisons among countries and categories of smokers. Tob Control 1996; 5: 52-56.

10. Zatoński W. Czy w demokracji żyje się zdrowiej? Rozwój sytuacji zdrowotnej w Polsce po 1988 roku [Is democracy healthier? Development of health situation in Poland after 1988]. Medycyna po Dyplomie 1996; 5: 21-23.

11. Zatoński WA, Boyle P. Health transformations in Poland after 1988. J Epidemiol Biostat 1996; 4: 183-197.

12. McKee M, Zatoński W. How the cardiovascular burden of illness is changing in eastern Europe. Evid Based Cardiovasc Med 1998; 2: 39-41.

13. Zatonski WA, McMichael AJ, Powles JW. Ecological study of reasons for sharp decline in mortality from ischaemic heart disease in Poland since 1991. BMJ 1998; 316: 1047-1051.

14. Zatoński W. The dynamics of mortality in Poland. In: Health and mortality issues of global concern. Population Division, United Nations Secretariat, New York 1999; 227-261.

15. Zatoński W and the HEM Project team. Closing the health gap in European Union. Cancer Center and Institute, Warsaw 2008.

16. Murray CJ, Lopez AD. Global and regional cause-of-death patterns in 1990. Bulletin of the World Health Organization 1994 72: 447-480.

17. Paniccia R. Economic shocks, impoverishment and povertyrelated mortality during the Eastern European transition. Working papers 126 . The United Nations University/World Institute for Development Economics Research, 1997.

18. Riphahn RT, Zimmermann KF. The transitions' mortality crisis in East Germany. Research for Action 42. The United Nations University/World Institute for Development Economics Research, 1997.
19. Varasovszky Z, Bain C, McKee M. Alcohol related mortality in Poland and Hungary: differences and similarities. J Epidemiol Comm Health 1997; 51: 167-171.

20. Zatoński W. Alcohol and health: what is good for the French may not be for the Russians. J Epidemiol Community Health 1998; 52: 766-767.

21. Sierosławski J. Spożycie alkoholu i polityka wobec alkoholu $\mathrm{w}$ ocenie społecznej - raport $\mathrm{z}$ badań ankietowych [Alcohol consumption and alcohol policy in popular estimation - report from questionnaire research]. Instytut Psychiatrii i Neurologii, Warszawa 1992

22. Habrat B, Pużyski S. Szkody zdrowotne spowodowane piciem alkoholu w Polsce [Harmful heath effect causes by drinking alcohol in Poland]. In: Stan zdrowia Polaków [Health status of Poles]. Zatoński W, Hulanicka B, Tyczyński J (eds.). Monografie Zakładu Antropologii Polskiej Akademii Nauk, Wrocław 1996.

23. Bruthans J, Bruthansova D, Cervenkova A. Rapid downturn in Czech CVD mortality: the role of social and economic changes [abstract]. Can J Cardiol 1997; 13 (suppl B): abstract no. 0430.

24. Bobak M, Skodova Z, Pisa Z, et al. Political changes and trends in cardiovascular risk factors in the Czech Republic, 1985-92. J Epidemiol Community Health 1997; 51: 272-277.

25. Jha P, Peto R, Zatoński W, et al. Social inequalities in male mortality, and in male mortality from smoking: indirect estimation from national death rates in England and Wales, Poland, and North America. Lancet 2006; 368: 367-370.

26. Zatoński W. Health status and tobacco smoking in Eastern European countries. Eur J of Cancer Prev 1996; 5: 135-136.

27. Zatoński WA, Sulkowska U, Mańczuk M, et al. Liver cirrhosis mortality in Europe, with special attention to Central and Eastern Europe. Eur Addict Res 2010; 16: 193-201.

28. Zatonski WA, Willett W. Changes in dietary fat and declining coronary heart disease in Poland: population based study. BMJ 2005; 331: 187-8.

29. Zatonski W, Campos H, Willett W. Rapid declines in coronary heart disease mortality in Eastern Europe are associated with increased consumption of oils rich in alpha-linolenic acid. Eur J Epidemiol 2008; 23: 3-10.

30. De Lorgeril M, Renaud S, Mamelle S, et al. Mediterranean alphalinolenic acid-rich diet in secondary prevention of coronary heart disease. Lancet 1994; 343: 1454-1459. 